\title{
SISTEM INFORMASI INVENTORY BARANG BERBASIS WEB
}

\section{(Studi Kasus : Koperasi Kasongan Usaha Bersama Bantul)}

\author{
Agus Sujarwadi ${ }^{1}$, Fatoni $^{2}$ \\ Informatika, Universitas Teknologi Yogyakarta \\ Jl. Siliwangi (Ringroad Utara), Jombor, Yogyakarta \\ Email: agus.Sujarwadi@uty.ac.id, phatonboy@gmail.com
}

\begin{abstract}
Inventory system is a system that serves to know the inventory of goods in a place. Inventory systems are widely used or developed in a place with a variety of technologies. The existing problem at cooperative kasongan business together is not yet availability of inventory system of goods not efficient so that, when employees perform data collection sometimes still occur miscalculation because in data collection goods not yet computerized. Therefore, in this final project will be built web-based inventory information system,so that information about the stock of goods available in cooperative can be known clearly and in detail. This inventory application is built using the programming language Php and mysql as database and several other stages in the design of this system. The stages in the design of this system is the analysis and design of systems, system design, coding, system implementation and system testing. Based on the concept and design of this system then, it can be concluded that the web-based inventory of goods applications was built with the aim that in the management of data entry and discharge of goods more orderly and computerized so as to avoid the problem of miscalculation done by employees when collecting goods in cooperative Bantul.
\end{abstract}

Keywords: Inventory, PHP, MySql

\section{PENDAHULUAN}

Kasongan usaha bersama adalah salah satu instansi yang bergerak di bidang produksi dan penjualan kerajinan panel bambu serta gerabah yang beralamat di Desa Bangunjiwo, Kasihan, Bantul. Kegiatan setiap harinya kasong an usaha bersama yaitu memproduksi dan memenuhi permintaan penjualan kerajinan panel bambu dan gerabah serta ekspor panel bambu ke luar negri. Negara yang menjadi tujuan ekspor panel bambu meliputi, Perancis, India, Afrika Selatan dan NewZeland sedangkan untuk pasar lokalnya yaitu, Yogyakarta, Cilacap, Batang, Magelang dan Klaten.

Jenis barang yang diproduksi dan dijual koperasi kasongan usaha bersama terdiri dari dua jenis yaitu, terakota (gerabah) 
dan panel bambu. Jenis terakota (gerabah) yang diproduksi meliputi, gentong, guci hias meja, patung semar, patung binatang, peralatan masak dan vas bunga dengan ukuran mulai dari 40$100 \mathrm{~cm}, 50-250 \mathrm{~cm}$. Jenis panel bambu meliputi panel kecil $100 \mathrm{~cm}$, panel sedang $150 \mathrm{~cm}$ dan panel besar $200 \mathrm{~cm}$.

Pelayanan yang cepat dan memuaskan pelanggan adalah hal yang sangat diutamakan oleh koperasi kasongan usaha bersama. Pada saat kondisi penjualan ramai dan dengan keterbatasan jumlah karyawan, membuat transaksi penjualan barang tidak bisa dilakukan secara cepat dan efisien. Pembelian bahan produksi pada suplier juga kurang efisien dikarenakan sistem yang berjalan saat ini masih menggunakan perhitungan dan pencatatan secara manual serta belum terkomputerisasi. Terkadang terjadi kesalahan hitung pada saat pendataan persediaan barang baik itu barang produksi ataupun barang yang sudah jadi dan siap untuk dijual. Seiring berjalannya waktu kegiatan di koperasi kasongan usaha bersama ternyata masih mengalami masalah pada proses pendataan persediaan dan keluar masuknya barang yang ada di gudang.
Radika Purwanti (2011), melakukan penelitian tentang implementasi sistem komputerisasi dalam perkantoran dalam hal pengolahan berkas-berkas data yang dibutuhkan untuk inventaris perkantoran. Penelitian ini menggunakan DBMS Ms. Access dan visual basic 6.0. Input dari sistem yang dibuat dalam penelitian ini berupa data karyawan, alat cetak kartu karyawan, dan output berupa laporan peminjaman barang.

Penelitian yang dilakukan oleh Yulianti (2011), mengenai analisa sistem informasi inventory Control di PT.Panarub Industri”. Kesimpulan dari penelitian ini yaitu, bahwa pada pengecekan barang jadi sering terjadi kesalahan dalam penginputan data yang berulang-ulang di karenakan pengecekannya yang masih manual. Dalam penelitian ini menghasilkan aplikasi yang memudahkan pengguna dalam melakukan pengecekan barang jadi, barang dalam proses, dan data laporan.

Penelitian yang dilakukan oleh Choirul Munawar (2011), mengenai desain sistem informasi persediaan barang produksi pada PT.Panarub Industri. Penelitian ini terdapat kesimpulan bahwa pada pengolahan 
persediaan barang masih menggunakan semi komputer, yaitu dengan menggunakan MS. Exel dalam pembuatan laporan, sehingga laporan yang dihasilkan kurang memuaskan dan informasi tidak tepat waktu, dengan adanya sistem persediaan barang produksi yang baik dan terencana diharapkan akan lebih efektif dan efisien dalam proses produksi barang serta maenghasilkan output berupa laporan produksi secara rinci.

Berdasarkan uraian masalah yang telah digambarkan di atas maka, solusi yang tepat dari permasalahan tersebut adalah dengan menggunakan aplikasi inventori barang. Perancangan aplikasi ini menggunakan bahasa pemrograman Php dan MySql sebagai databasenya. Aplikasi inventori barang ini di maksudkan agar karyawan atau pengguna pada koperasi kasongan usaha bersama dapat dengan mudah dalam proses pengelolaan data barang. Selain itu diharapkan bisa memberikan solusi mengenai masalah yang ada di koperasi kasongan usaha bersama Bantul.

\section{METODE PENELITIAN}

Metode penelitian yang dilakukan penulis dalam peneliti untuk mendapatkan data yang lengkap dan akurat, yaitu dilakukan dengan metode pengumpulan data sebagai berikut

a. Metode Observasi

Observasi adalah suatu metode pengumpulan data dengan cara tanya jawab, melakukan pencatatan secara cermat dan sistematik, dengan mengamati dan mencatat segala kegiatan yang ada pada koperasi kasongan usaha bersama Bantul. Dengan cara mengamati peneli akan menemukan fakta-fakta sistematis dan benar.

b. Metode Wawancara

Merupakan metode yag digunakan dengan cara wawancara dengan pemilik atau karyawan yang bersangkutan guna mendapatkan informasi sebagi bahan dalam penulisan laporan proyek tugas akhir ini.

c. Metode Studi Pustaka

Merupakan metode pengumpulan data dengan cara mengumpulkan data-data dari berbagai sumber yang mendukung penelitian baik itu dari buku, jurnal ilmiah, maupun artikel lainya yang mendukung penelitan.

\section{1) Analisis Sistem}

Setelah pengumpulan data maka akan dilakukan analisis sehingga penulis akan 
mengetahui alur sistem yang akan dibuat, data barang masuk, data penjualan, data retur barang dan data stok barang.

\section{2) Desain Sistem}

Setelah dilakukan pengumpulan data dan analisis, tahap selanjutnya adalah pembuatan Diagram Konteks, Diagram Jenjang, Diagram Alur Data (DAD), Entity Relationship Diagram (ERD), desain tabel, relasi tabel, perancangan input dan output yang nantinya akan diaplikasikan kedalam sistem. Tahap ini dibagi lagi sebagai berikut :

a. Perancangan desain sistem meliputi perancangan DAD dan ERD perancangan DAD dan ERD ditunjukan sebagai pembuatan gambar alur sistem secara umum serta penjelasan tentang entitas yang terlibat di dalam sistem.

b. Perancangan basisdata meliputi perancangan tabel-tabel yang nantinya digunakan oleh sistem yang akan dibangun dan juga akan digambarkan mengenai hubungan antar masingmasing tabel dalam relasi tabel.

c. Perancangan antar muka terdiri dari :

- Perancangan desain antar muka proses input meliputi perancangan menumenu yang akan digunakan salam sistem.
- Perancangan desain antar muka proses meliputi proses transaksi, proses supplier, dan proses data barang.

- Perancangan desain antar muka output meliputi faktur penjualan, laporan data barang, data supplier.

1) Implementasi Sistem

Yaitu proses penerapan sistem yang telah dibuat menggunakan Entity Relationship Diagram (ERD), Diagram Alur Data (DAD) serta bahasa pemrograman PHP dan Mysql sebagai databasenya. Pengujian sistem dilakukan untuk memastikan ada atau tidaknya masalah yang muncul. Setelah pengujian selesai dilakukan, barulah sistem siap untuk digunakan sesuai dengan desain input dan outputnya.

\section{2) Pengujian Sistem}

Pengujian sistem dilakukan dengan dua tahap yaitu pengujian eksternal dan pengujian internal. Pengujian eksternal dilakukan oleh pengguna, sedangkan untuk pengujian internal dilakukan dengan menggunakan metode black box testing yang di uji oleh pembuat sistem. Pengujian tersebut akan menentukan apakah sistem sudah siap dan layak 
untuk dipakai atau masih perlu di perbaiki.

\section{3) Perangkat Pendukung}

Perangkat lunak adalah aplikasi komputer yang digunakan dalam membangun sistem. Adapun perangkat lunak yang digunakan guna mendukung kinerja sistem yaitu :
a. Sistem operasi : Microsoft Windows 7
b. Bahasa Pemrograman : Php
c. Aplikasi Basis Data : SQL Yog
d. Aplikasi web server : Xampp

Perangkat keras merupakan sistem komputer yang digunakan dalam membangun sistem. Perangkat keras yang digunakan meliputi

a. Prosesor intel (R) CoreTM 2 Duo

b. Memori $2 \mathrm{~GB}$

c. VGA

d. Kapasitas penyimpanan $500 \mathrm{~GB}$

e. LCD 14"

\section{HASIL DAN PEMBAHASAN}

\section{Analisis Sistem}

\section{Inventory (persediaan) barang} merupakan suatu sistem yang memang sangat di butuhkan khususnya di koperasi kasongan usaha bersama Bantul karena saat ini proses pendataan barang masih mengggunakan pembukuan saja sehingga, jika menggunakan sistem inventory barang ini akan menjadi lebih tertata dan efisien waktu pada saat proses pendataan barang.

a) Analisis Sistem yang Berjalan

Sistem yang berjalan pada koperasi kasongan usaha bersama masih memiliki kendala, dikarenakan proses bisnis pada koperasi kasongan usaha bersama masih menggunakan sistem manual, di antaranya mulai dari proses penjualan barang, pembuatan laporan penjualan, penyimpanan barang, sampai pemesanan barang dari supplier. Hal ini mengakibatkan terjadinya hambatan yang sangat berpengaruh pada proses penjualan.

Disamping itu pada bagian
administrasi masih belum tercatat dengan baik dan hanya menggunakan buku besar saja, sehingga apabila ingin menyimpan data-data tersebut, maka harus membuka buku besar terlebih dahulu yang mana didalamnya terdapat data-data instansi, begitu juga jika ingin mencari data-data yang diperlukan maka harus kembali membuka buku besar tersebut dan mencari satu per satu, hal ini tentunya membutuhkan ketelitian dan tentunya sangat membuang waktu, 
sehingga sering terjadi kehilangan data dan dengan buku besar dalam penyimpanan data ini sangat tidak akurat. Hal ini mengakibatkan pemilik atau pimpinan tidak dapat mengetahui dengan pasti berapa pemasukan dan pengeluaran tiap bulanya.

Kemudian tidak adanya pengontrolan pada semua bidang seperti pada gudang tidak memiliki pencatatan stok barang yang mengakibatkan bagian gudang dan penjualan tidak terintregasi dengan baik, sehingga sering terjadi barang hilang, kekurangan barang sampai penumpukan barang. Demikian sistem yang sedang berjalan pada koperasi kasongan usaha bersama dapat digambarkan pada flowchart gambar 4.1.

b) Perancangan Sistem Yang Diusulkan

Setelah melakukan analisa dan mengetahui kelemahan-kelemahan pada sistem yang sedang berjalan, maka dapat dibuat sistem baru yang dapat memperbaiki kekurangan-kekurangan pada sistem sebelumnya sehingga bisa membantu untuk memproses informasi dengan lebih cepat. Adapun gambaran sistem ini mencakup diagram konteks, diagram alir data yang menjelaskan tentang alur sistem mulai dari input sistem hingga output sistem. Berikut adalah flowchart

c) Gambaran Umum Sistem Yang Diusulkan

Gambaran sistem yang diusulkan bertujuan untuk menghasilkan perancangan sistem informasi yang terkomputerisasi. Usulan perancangan yang dilakukan adalah merubah sistem informasi pengelolaan data barang yang belum terkomputerisasi menjadi terkomputerisasi.

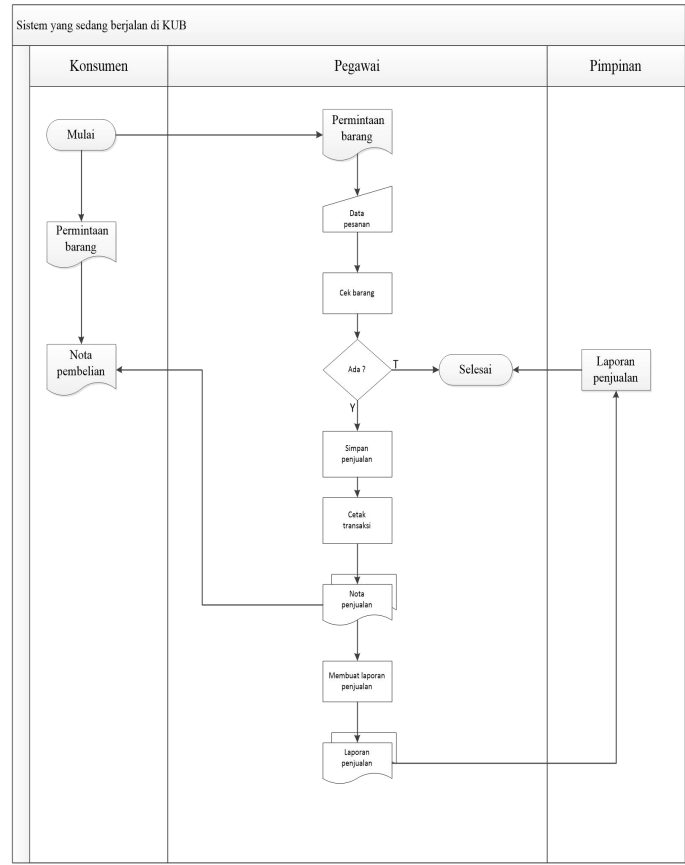

Gambar 4.1 Flowchart sistem yang sedang berjalan di KUB

Sistem yang diusulkan di kub pada gambar 4.2. 


\section{Perancangan Sistem}

Perancangan sistem yaitu tahap merencanakan dan mendesain sistem yang akan dibangun dan dikembangkan.

Proses perancangan sistem basis data ini yaitu dengan menggunakan diagram konteks, diagram berjenjang dan diagram arus data $(D A D)$.

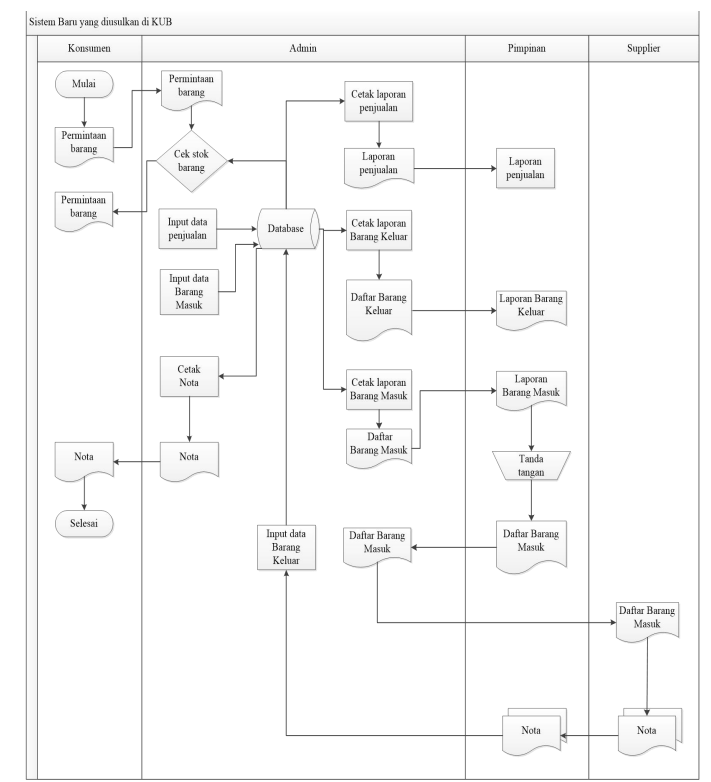

Gambar 4.2 Flowchart sistem yang diusulkan

a) Diagram Konteks
Diagram konteks adalah diagram yang menggambarkan proses sistem dan mencakup masukan-masukan dasar, sistem umum serta output, diagram ini merupakan tingkatan tertinggi dalam diagram alur data dan mewakili semua proses yang ada, menunjukan alur kerja sistem secara keseluruhan, diagram tersebut menggambarkan aliran data secara sederhana, proses tersebut diberi nomor nol. Semua entitas eksternal yang ditunjukan pada diagram konteks berikut aliran-aliran data menuju dan dari sistem. Diagram konteks ini memiliki proses admin dan pelanggan.

b) Diagram Jenjang

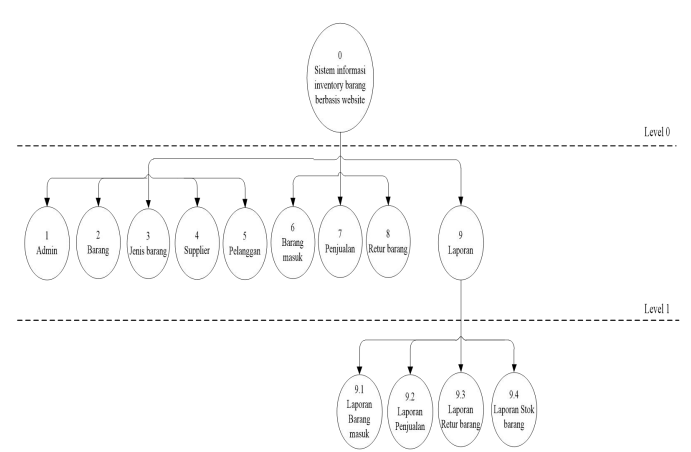

Gambar 4.4 Diagram Jenjang

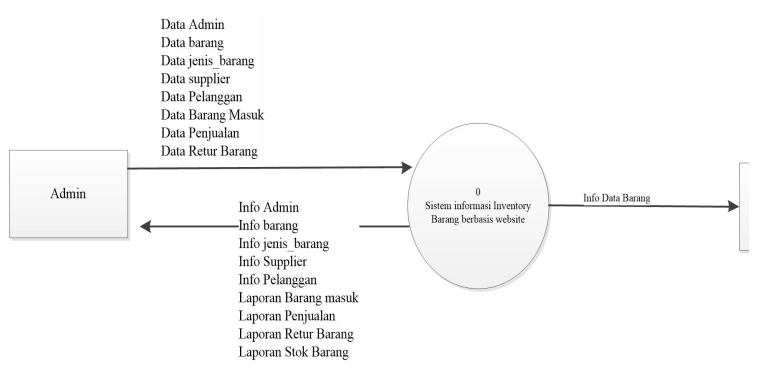

Gambar 4.3 Diagram Konteks 
a) Diagram Alur Data $(D A D)$ Level 1

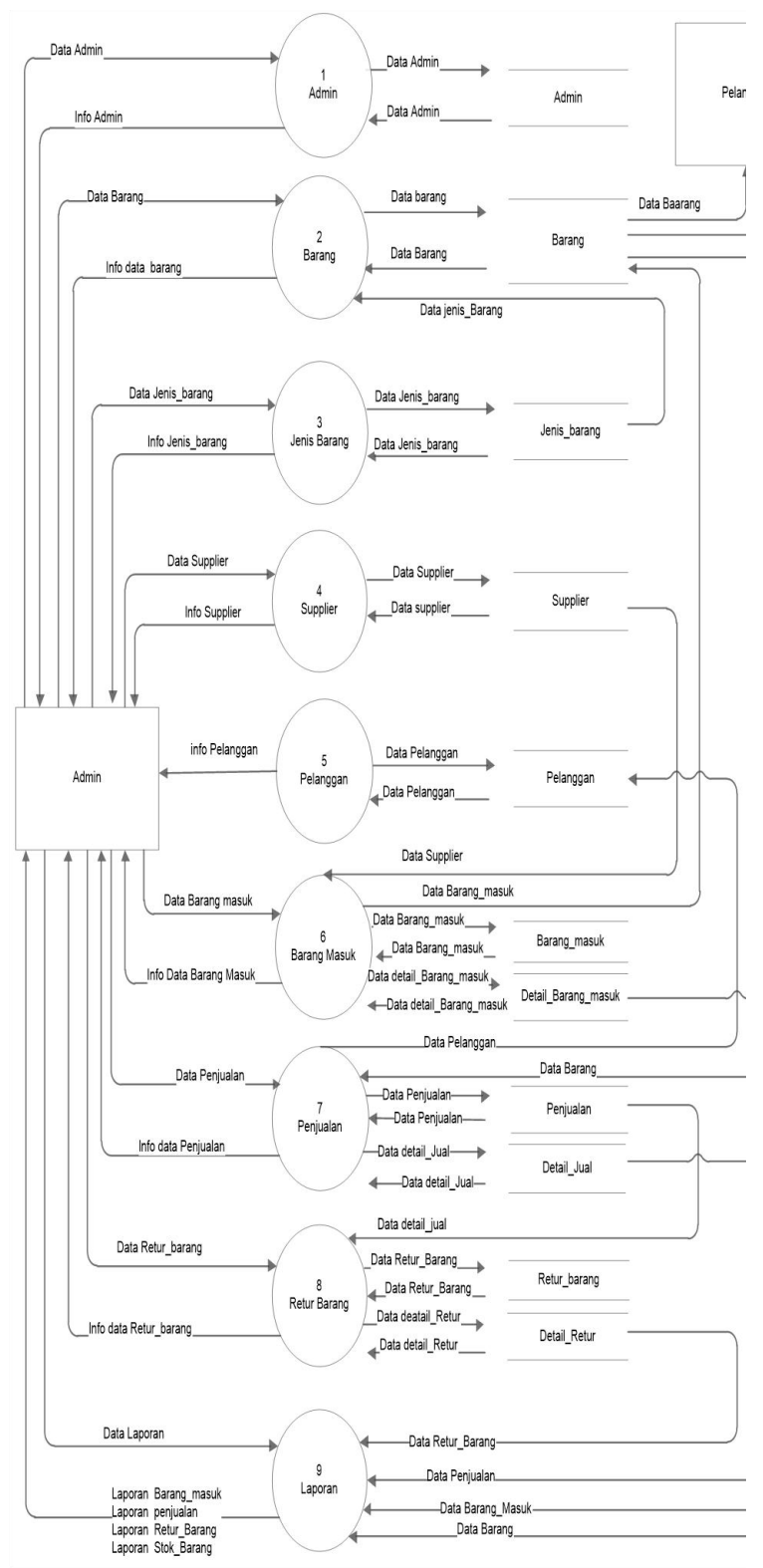

b) Diagram Alur Data ( $D A D)$ Level 2

Proses Laporan

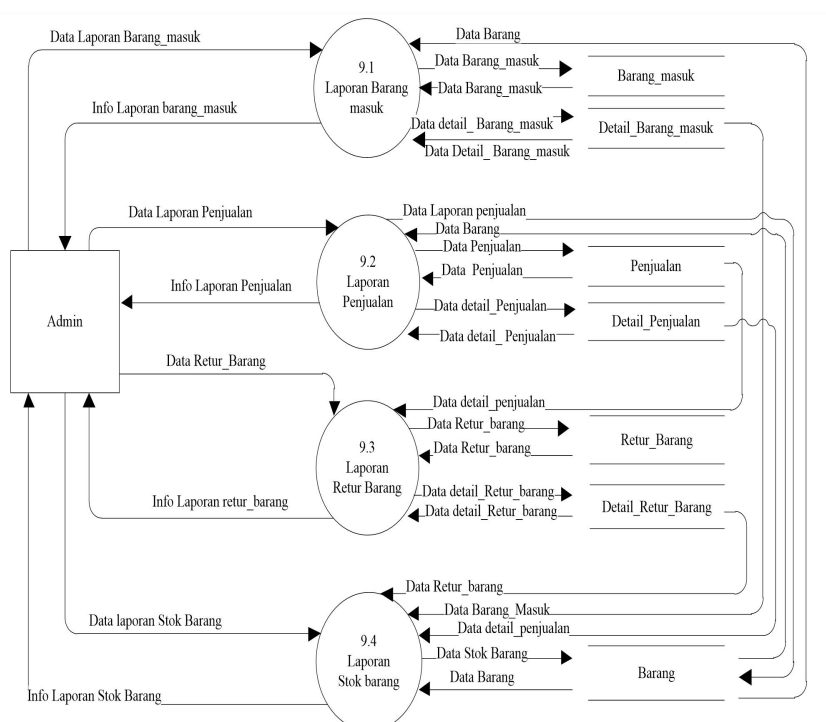

Gambar 4.6 Diagram Alur Data level 2

Proses Laporan

Diagram level 2 proses laporan merupakan diagram yang menggambarkan alur laporan yang keluar dari sistem setelah pemrosesan data. Laporan ini berisi mengenai laporan barang masuk, barang penjualan, retur barang, dan stok barang.

Gambar 4.5 Diagram Alur Data level 1

Diagram alur data level satu ini merupakan diagram turunan dari jenjang yang menggambarkan alur pemrosesan data yang ada di sistem secara keseluruhan mulai dari input, transaksi hingga laporan atau output serta hubungan antar tabel. 
c) Entity Relationship Diagram (ERD)

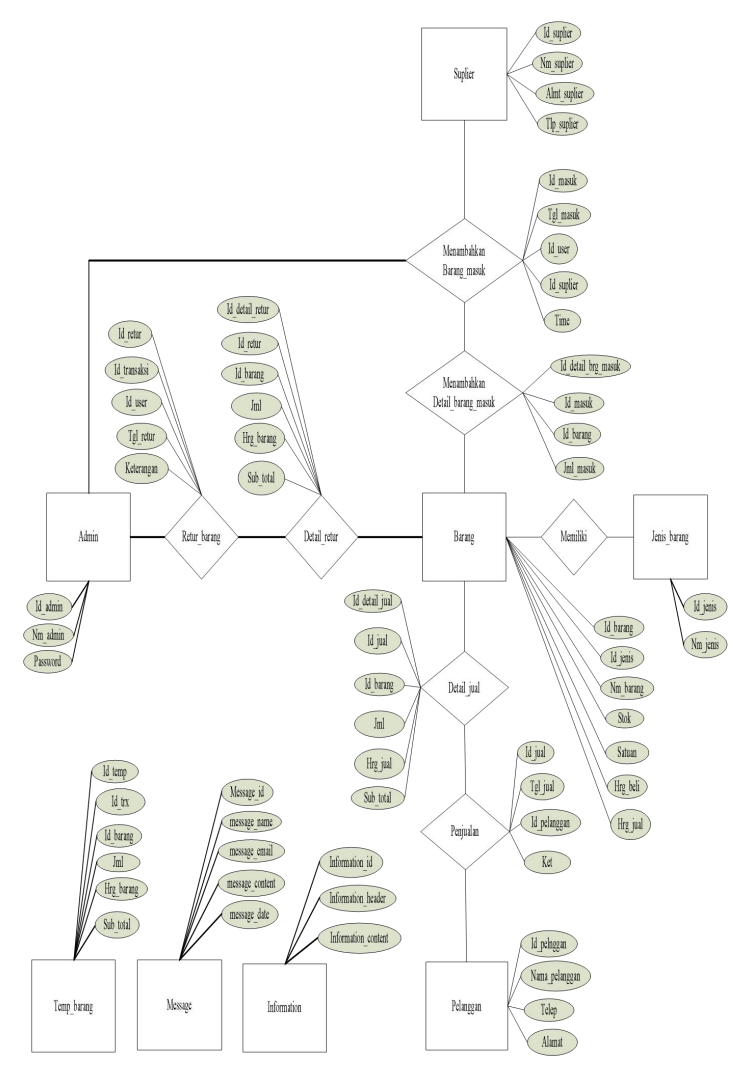

Gambar 4.7 Entity Relationship

Diagram

ERD ini merupakan model yang menggambarkan hubungan antar entitas data yang terhubung dan yang tidak terhubung berdasarkan objek-objek dasar yang mempunyai hubungan antar relasi.

d) Relasi Antar Tabel

Relasi antar tabel ini merupakan relasi yang menggambarkan hubungan antar tabel yang mempresentasikan hubungan natara objek di sistem inventory barang dan berfungsi untuk mengatur operasi suatu database .

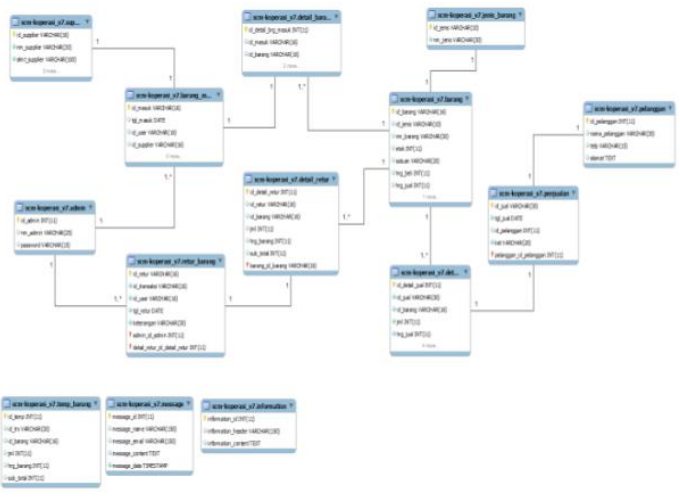

Gambar 4.8 Relasi Antar Tabel

Hasil dan implementasi dari aplikasi inventory barang berbasis web Tugas Akhir Jurusan Informatika Universitas Teknologi Yogyakarta memiliki Output Sistem diantaranya:
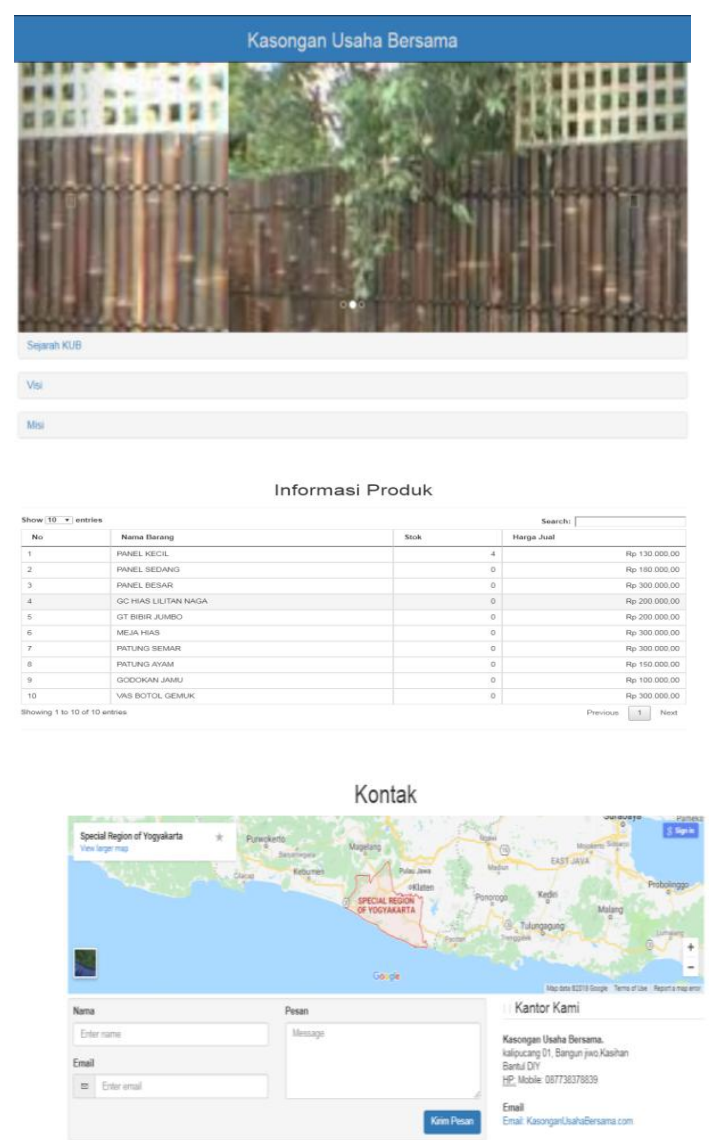

Gambar 5.1 Halaman

UtamaPelanggan 
Halaman pelanggan merupakan halaman yang yang digunakan oleh pelanggan untuk melihat data barang sebelum melakukan pembelian. Halaman ini hanya berisi informasi mengenai data barang yang ada untuk melakukan pembelian barang yang diinginkan pelanggan harus datang langsung ke koperasi kasongan usaha bersama Bantul.

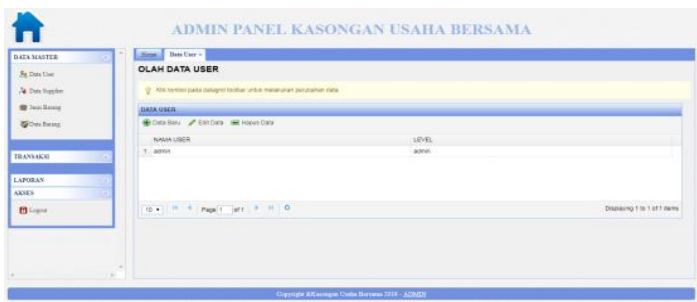

Gambar 5.2 Halaman Master Admin

Halaman master admin ini merupakan halaman yang digunakan oleh admin untuk mengelola data admin beserta proses input, edit, dan hapus. Halaman ini berisi mengenai data admin yang bisa login ke sistem.

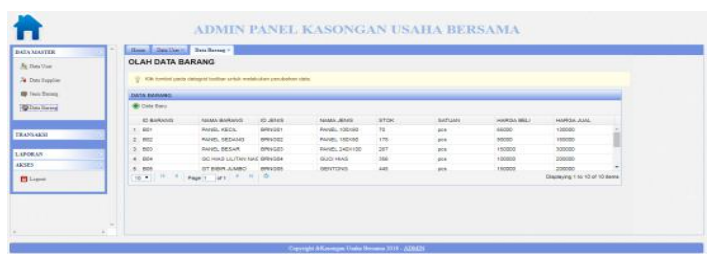

Gambar 5.3 Halaman Master Barang

Halaman master barang merupakan halaman yang digunakan oleh admin untuk mengelola data barang. Halaman ini berisi mengenai data barang yang ada di koperasi kasongan usaha bersama
Bantul, di dalam halam ini admin bisa melakukan input barang sesuai barang yang akan dijual.

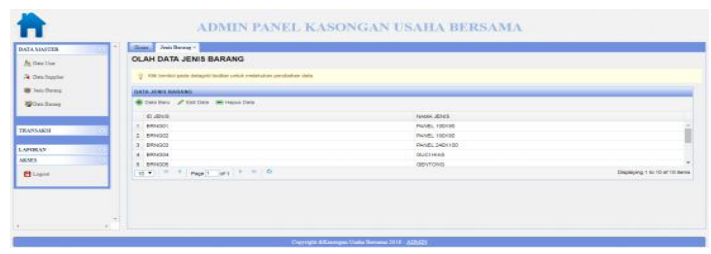

Gambar 5.4 Halaman Master

Jenis Barang

Halaman master jenis barang merupakan halaman yang digunakan oleh admin untuk mengelompokan data barang berdasarkan jenis barang yang ada serta proses input input, edit, dan hapus yang bisa dilakukan oleh admin.

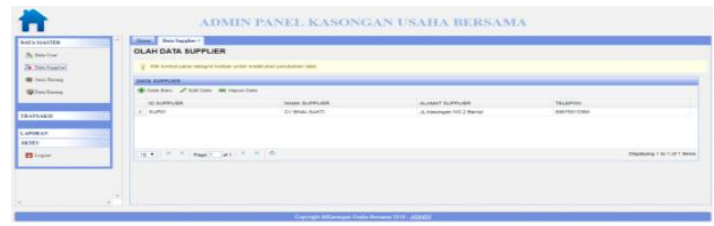

Gambar 5.5 Halaman Master Supplier

Halaman master supplier merupakan halaman yang digunakan oleh admin untuk mengelola data supplier, di dalam halamn ini admin akan mengelola data supplier mulai dari proses penginputan data suplier, edit, dan hapus.

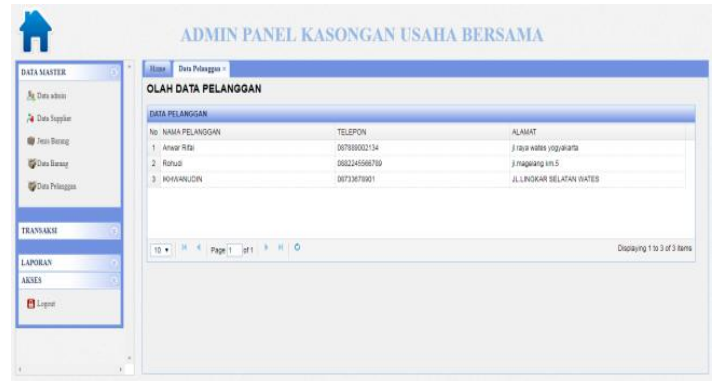

Gambar 5.6 Halaman Master Pelanggan 
Halaman master pelanggan merupakan halaman yang digunakan oleh admin untuk melihat data pelnggan yang sudah melakukan transaksi pembelian barang di koperasi kasongan usaha bersama Bantul.

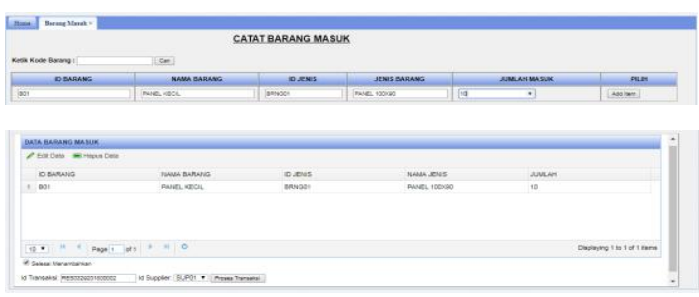

Gambar 5.7 Halaman Transaksi Barang Masuk

Halaman transaksi barang masuk merupakan halamn yang digunakan oleh admin untuk mengelola data brang yang masuk dari supplier untuk dimasukan ke dalam data barang sehingga data barang akan otomatis menambah jika ada data barang yang masuk dan nantinya data ini akan di proses untuk dijadikan laporan bulanan.

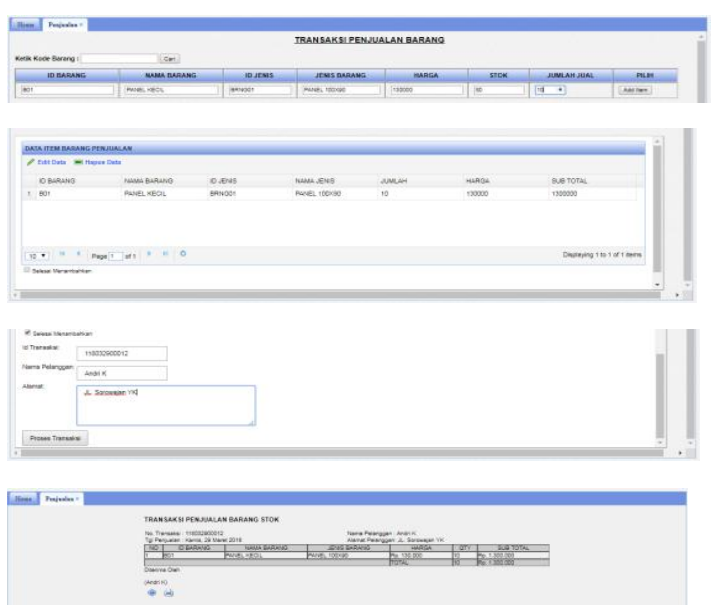

\section{Gambar 5.8 Halaman Transaksi Penjualan \\ Halaman transaski penjualan merupakan halaman yang digunakan}

oleh admin untuk mengelola data penjualan barang. Data ini nantinya bisa di gunkan oleh admin untuk dijadikan laporan bulanan sesuai data yang telah terjual.

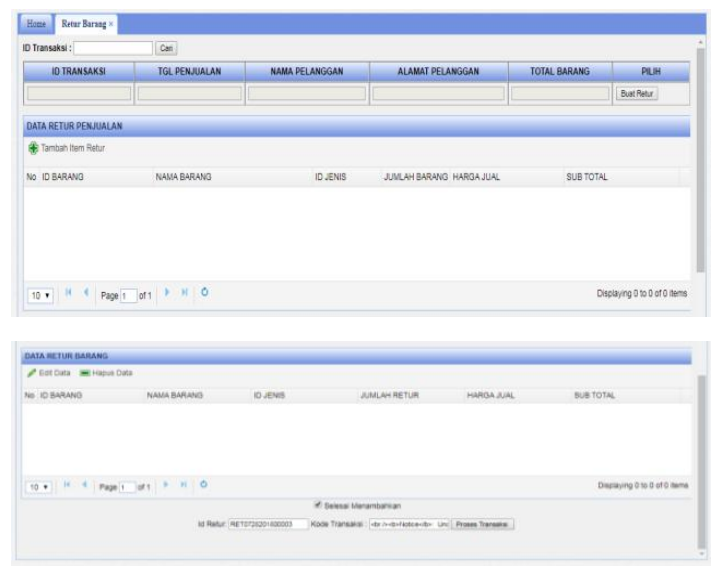

Gambar 5.9 Halaman Transaksi Retur Barang

Halaman transasksi retur barang merupakan halaman yang digunakan oleh admin untuk mengelola data barang yang akan dan telah diretur dari pelanggan. Halaman ini nantinya akan digunakan oleh admin untuk dijadikan laporan kepada pimpinan sehingga jumlah data stok barang akan selalu terkontrol karena sudah terkomputerisasi.

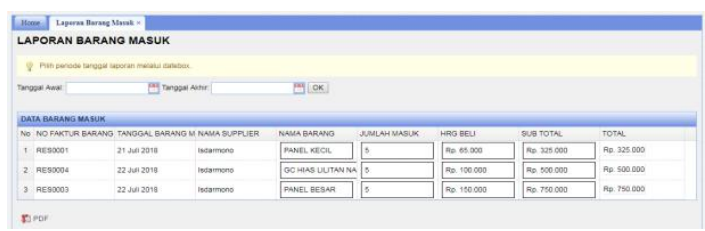

Gambar 5.10 Halaman Laporan Barang Masuk

Halaman laporan barang masuk merupakan halaman yang digunakan 
oleh admin untuk mengelola data laporan barang. Laporan barang masuk ini bisa dilihat dengan cara memasukan tanggal awal dan akhir yang dinginkan setelah menginputkan tanggal data yang diinginkan akan tampil setelah tampil datanya bisa langsung di prin dan dijadikan laporan atau dilihat saja.

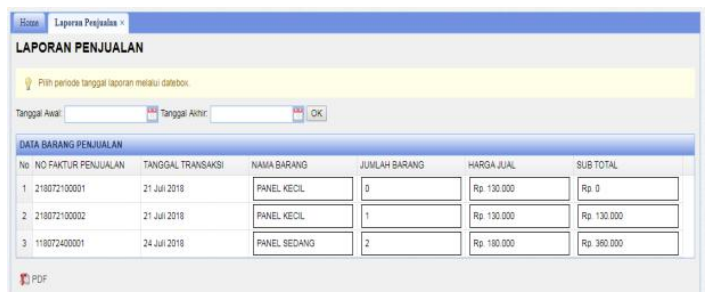

Gambar 5.11 Halaman laporan barang Halaman Laporan Barang

Penjualan merupakan halaman yang berisi mengenai data brang yang telah dijual, data brang yang telah dijual bisa dilihat oleh admin dengan cara memasukan tanggal awal dan akhir kemudian akan tampil data yang diinginkan, data tersebut bisa langsung diprin untuk dijadikan laporan atau hanya dilihat saja.

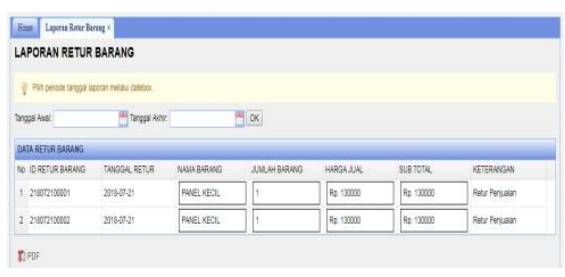

Gambar 5.12 Halaman Laporan Retur Barang

Halaman laporan retur barang merupakan halaman yang berisis mengenai data barang yang telah diretur. Data barang yang telah diretur bisa dilihat oleh admin dengan cara memasukan tanggal awal dan akhir kemudian akan tampil data baran yang diinginkan data barang yang tampil bnisa langusng diprin dan dijadikan laporan atau hanya dilihat saja.

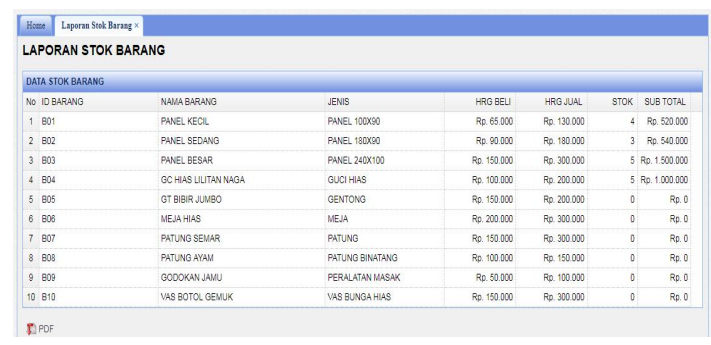

Gambar 5.13 Halaman Laporan Stok Barang

Halaman laporan stok barang merupakan halaman yang berisi mengenai keadaan jumlah barang yang ada setelah di proses oleh sistem. Data barang ini bisa dilihat oleha admin dengan cara mengklik menu stok barang kemudian akan tampil data barang yang diinginkan data barang yang tampil bisa langsung diprint dan dijadikan laporan bulanan atau hanya dilihat saja.

\section{KESIMPULAN}

\section{Berdasarkan rumusan masalah} yang ada maka dapat diambil kesimpulan mengenai cara membangun aplikasi inventory barang ini yaitu dibangun dengan menggunakan bahasa 
pemrograman PHP dan MySql sebagai databasenya. Aplikasi inventory barang ini dibagun untuk memudahkan admin atau karyawan dalam mengelola data stok barang yang ada di koperasi kasongan usaha bersama Bantul agar lebih tertata dan sistematis serta terkomputerisai, sehingga dapat menghidari dari keasalahan hitung pada saat pendataan data barang serta memudahkan karyawan dalam proses pembuatan laporan data barang per periode. Aplikasi inventory barang ini memiliki beberapa menu yang dapat digunakan oleh admin atau karyawan untuk mengelola data barang secara terkomputerisasi. Menu-menu yang ada meliputi data master yang terdiri dari (menu user, barang, jenis barang, supplier), transaksi yang terdiri dari (barang masuk, penjualan, retur barang masuk, retur barang penjualan), dan menu laporan yang terdiri dari (laporan barang masuk, penjualan, retur barang masuk, retur barang penjualan, stok barang). Aplikasi ini tidak membahas mengenai keamanan sistem.

\section{SARAN}

a. Sistem informasi inventory barang ini masih belum sepenuhnya sempurnya dan masih perlu adanya pengembangan lebih lanjut dimana sistem ini masih belum bisa mensinkronkan mengenai keuntungan dan kerugian.

b. Output dari sistem informasi inventory barang ini masih sebatas lingkup keluar masuknya barang yang ada di gudang saja, sehingga masih perlu adanya pengembangan lagi.

\section{DAFTAR PUSTAKA}

Ahmad Yani, Panduan Menjadi Teknisi jaringan Komputer, kawan pustaka, Ciganjur, Jagakarsa, 2012.

Al-Bahra Bin Lajamudin, Analisis dan desain sistem informasi, Graha ilmu Yogyakarta, 2009.

Munir, Rinaldi, Algoritma \& pemrograman dalam bahasa pascal dan C, Bandung, Informatika, 2010.

Raharjo, Budi, Belajar otodidak membuat database menggunakan Mysql, Bandung, Informatika, 2011.

Sidik, Betha dan Husni Iskandar Pohan, Pemrograman web dengan HTML, Bandung, Informatika, 2010.

Noviandi, Budi Mohamad, Perancangan sistem informasi inventory barang di Bank sampah Garut, Garut, Jurnal algoritma, Volume 9, STT Garut, 2012. 
Roger, S. Pressman, Ph.D., 2012,

Rekayasa Perangkat Lunak

(Pendekatan Praktisi) Edisi 7: Buku

1 “, Yogyakarta: Andi 